\title{
Article \\ High Phosphorus Acquisition and Allocation Strategy Is Associated with Soybean Seed Yield under Water- and P-Limited Conditions
}

\author{
Yun-Yin Feng ${ }^{1}$, Jin $\mathrm{He}^{1, *(\mathbb{D})}$, Yi Jin ${ }^{2,3}$ and Feng-Min $\mathrm{Li}^{3}$ (D) \\ 1 The Key Laboratory of Plant Resource Conservation and Germplasm Innovation in Mountainous \\ Region (Ministry of Education), College of Agriculture, Guizhou University, Guiyang 550025, China; \\ fengyunyin@139.com \\ 2 Key Laboratory of Vegetation Restoration and Management of Degraded Ecosystems, South China Botanical \\ Garden, Chinese Academy of Sciences, Xingke Road 723, Guangzhou 510000, China; yking1225@163.com \\ 3 State Key Laboratory of Grassland Agro-Ecosystems, Institute of Arid Agroecology, School of Life Sciences, \\ Lanzhou University, Lanzhou 730000, China; fmli@lzu.edu.cn \\ * Correspondence: hejin0811@163.com
}

check for updates

Citation: Feng, Y.-Y.; He, J.; Jin, Y.; Li, F.-M. High Phosphorus Acquisition and Allocation Strategy Is Associated with Soybean Seed Yield under Waterand P-Limited Conditions. Agronomy 2021, 11, 574. https://doi.org/ doi:10.3390/agronomy11030574

Academic Editor: Anita Ierna

Received: 23 February 2021

Accepted: 13 March 2021

Published: 18 March 2021

Publisher's Note: MDPI stays neutral with regard to jurisdictional claims in published maps and institutional affiliations.

Copyright: (c) 2021 by the authors. Licensee MDPI, Basel, Switzerland. This article is an open access article distributed under the terms and conditions of the Creative Commons Attribution (CC BY) license (https:// creativecommons.org/licenses/by/ $4.0 /)$.

\begin{abstract}
Both water stress and P deficit limit soybean seed yield, but the effects of water regimes and $\mathrm{P}$ application rates, their interaction on $\mathrm{P}$ status, acquisition, and partitioning, and their roles in yield performance have not been well-studied. Two soybean genotypes (Huangsedadou (HD) and Zhonghuang $30(\mathrm{ZH})$ ) with contrasting seed yield and root dry weight (DW) were used to investigate the $\mathrm{P}$ status, $\mathrm{P}$ acquisition, $\mathrm{P}$ partitioning, and yield formation under two water regimes (well-watered (WW) and cyclic water stress (WS)) and three P rates (0 (P0), 60 (P60), and 120 (P120) $\mathrm{mg} \mathrm{P} \mathrm{kg}^{-1}$ dry soil). The results show that increased $\mathrm{P}$ and water supply increased the seed yield, shoot and root DW and $\mathrm{P}$ concentrations and accumulations in different organs. Cultivar $\mathrm{ZH}$ had a significantly higher seed yield than HD at P60 and P120 under WS and at P0 under WW, but a lower seed yield at P60 and P120 under WW. Cultivar ZH had a significantly higher P harvest index and P acquisition efficiency, but a significantly lower shoot and root DW than HD. The interaction between water treatments and $\mathrm{P}$ rates had significant effects on leaf and stem P concentration. Cultivar ZH had significantly lower P partitioning to leaves and stems but significantly higher P partitioning to seeds than HD. The seed yield was positively correlated with leaf and seed P accumulations and $P$ acquisition efficiency under WS. We conclude that (1) adequate water supply improved the $P$ mobilization from leaves and stems at maturity, which may have improved the seed yield; and (2) the high $\mathrm{P}$ acquisition efficiency is coordination to high $\mathrm{P}$ partition to seeds to produce a high seed yield under water- and P-limited conditions.
\end{abstract}

Keywords: P partition; P acquisition efficiency; root dry weight; P harvest indices; seed yield

\section{Introduction}

Soybean is an important oil crop and the main source of protein consumed by humans. Soybean is not only a source of macronutrients such as $\mathrm{Ca}$ and minerals such as $\mathrm{Zn}$ and Fe, but also a source of secondary metabolites such as isoflavones and phytoestrogens [1,2]. A previous study showed that eating soybean-based products had the benefits of protection against kidney diseases, lowering of cholesterol, and prevention of cancer, diabetes, and obesity [3]. Soybean is important in intercropping systems due to its function in biological nitrogen fixation, which is important in sustainable agriculture [4].

Soybean is widely grown in tropical, subtropical, and temperate areas. The phosphorus $(\mathrm{P})$ in soil is often fixed by free aluminum and/or iron, leading to low soil-available $\mathrm{P}[5,6]$, and $\mathrm{P}$ deficit is a main nutritional factor limiting the soybean yield. Applying $\mathrm{P}$ is an efficient way to increase soil-available $\mathrm{P}$, but $\mathrm{P}$ is a non-renewable resource and $\mathrm{P}$ 
resources will be exhausted in the near future [7]. Thus, developing new soybean varieties with a high $P$ acquisition ability is a sustainable and economical endeavor [8].

$P$ acquisition mainly occurs in the roots and most studies have found that root traits such as root length and root density are closely linked to $\mathrm{P}$ uptake when soil-available $\mathrm{P}$ is low [9-11]. High adventitious root and lateral root density contribute to the high root P-uptake efficiency, which is associated with soybean seed yield during drought [10]. The shallow root growth angle and low metabolic cost of adventitious roots facilitate P uptake and improve yield performance in soils with low P availability [12-14]. Jia et al. [11] found that high lateral root density was associated with high seed yield and $\mathrm{P}$ accumulation in maize. Thus, root traits play an important role in P acquisition efficiency when soilavailable $P$ is limited [15].

The $\mathrm{P}$ partition to seed, which is shown as the $\mathrm{P}$ harvest index at maturity, was significantly positively correlated with the seed yield under different environments in common beans, indicating that $\mathrm{P}$ partitioning plays an important role in yield performance [16]. Variation in the $P$ harvest index in wheat was observed [17]; the P partition was associated with the yield performance in maize [18]. In barley, a high $P$ harvest index was associated with the yield performance when the soil P was low [19]. However, the role of P partitioning in soybean yield performance and the relationship between $\mathrm{P}$ acquisition and $\mathrm{P}$ partitioning are unknown.

Water shortage is the main abiotic stress limiting soybean yield [20-23]. Furthermore, water stress reduces the mobility of $\mathrm{P}$ in soil [24]. Previous studies showed that P application could eliminate the adverse effects of drought on seed yield $[10,25]$. One possible mechanism is that $\mathrm{P}$ application could increase the water usage at the flowering and pod formation stages, thus improving seed yield during drought [26]; however, the effects of the interaction between drought stress and $\mathrm{P}$ application on leaf $\mathrm{P}$ status and $\mathrm{P}$ partitioning to different organs are not known.

Drought events in arid and semi-arid areas are predicted to increase in the future [27]. With depletion of the non-renewable P resource, soybean yield will be threatened by both drought stress and low soil-available P. Improving soybean yield under water and $P$ deficits is a big problem, and revealing the underlying mechanisms will accelerate the breeding of new soybean cultivars with high seed yield under both water and P deficits. Two soybean cultivars with contrasting root dry weight (DW) were used in this study to (1) compare the $\mathrm{P}$ acquisition efficiency, $\mathrm{P}$ concentration, and $\mathrm{P}$ accumulation in different organs with $\mathrm{P}$ partitioning to different organs under different water regimes and $\mathrm{P}$ rates; (2) investigate the effects of the interaction of the water regime and P rate on organ P status and $\mathrm{P}$ partitioning; and (3) reveal the relationship between $\mathrm{P}$ acquisition and $\mathrm{P}$ partitioning and their roles in yield performance.

\section{Materials and Methods}

A pot experiment was carried out in a rain shelter at the Yuzhong Experiment Station $\left(35^{\circ} 51^{\prime} \mathrm{N}, 104^{\circ} 07^{\prime} \mathrm{E}\right.$, altitude $1620 \mathrm{~m}$ ) of Lanzhou University during the soybean growing season (29 April to 3 October) in 2015. The soybean (Glycine max (L.) Merr.) genotypes evaluated in this study were Huangsedadou (HD) and Zhonghuang $30(\mathrm{ZH})$. Our previous research has found that Huangsedadou has a higher root DW and a lower seed yield than Zhonghuang 30 under different water levels $[10,22,26,28]$.

The pots were composed of PVC tubes of length $1.05 \mathrm{~m}$ and diameter $0.16 \mathrm{~m} ; 36$ pots ( 2 cultivars $\times 2$ water treatments $\times 3$ P rates $\times 3$ replicates) were used. A three-factorial (water treatments, P levels, cultivars) randomized complete block design was used in this study and the pots were moved every week to avoid border effects. The soil used was obtained from the field and was mixed with vermiculite $(\mathrm{V}: \mathrm{V}=3: 1)$. The soil-available $\mathrm{P}$ concentration in the mixed soil was $2.0 \mathrm{mg} \mathrm{kg}^{-1}$. There were three $\mathrm{P}$ rates $(0$ (P0), 60 (P60), and 120 (P120) $\mathrm{mg} \mathrm{P} \mathrm{kg}^{-1}$ dry soil) applied as $\mathrm{NH}_{4} \mathrm{H}_{2} \mathrm{PO}_{4}$ to the top $0-40 \mathrm{~cm}$ of the soil. Two seeds were sown in each pot and only one was left after germination. Two water treatments were imposed at 15 days after sowing (DAS): well-watered (WW), which 
maintained the soil water content (SWC) within $85 \%-100 \%$ of pot capacity (PC); and cyclic water stress (WS), which withheld water until the SWC decreased to $30 \%$ of PC, then re-watered to $100 \%$ PC, repeating this drying and re-watering process until maturity [29]. There were 3-5 water cycles applied before physiological maturity, which was defined as when $95 \%$ of the pods were brown [30].

\subsection{Yield Performance}

The plants were harvested at physiological maturity (136-147 DAS). The leaves were collected during the life cycle of the soybean, with stems and pods harvested separately. The leaves, stems, and pods were dried and weighed as described above. The roots were carefully washed with tap water, collected, dried at $80^{\circ} \mathrm{C}$ for 3 days, and then weighed. Seeds were removed from the pods by hand, dried at $80^{\circ} \mathrm{C}$ for 3 days, and weighed to get the seed yield. All dried leaves, stems, roots, and seeds were stored and used to determine the $\mathrm{P}$ concentration.

\subsection{P and N Concentration Determined in Different Organs}

All samples used in this study were ground to fine powder by an ultra centrifugal mill (ZM200, Retsch, GmbH, Düsseldorf, Germany). About $0.2 \mathrm{~g}$ of each sample was weighed and digested with $\mathrm{H}_{2} \mathrm{O}_{2}-\mathrm{H}_{2} \mathrm{SO}_{4}$. The digested liquid was transferred to a volumetric flask $(100 \mathrm{~mL})$ and distilled water was added to the volumetric flask until the volume reached $100 \mathrm{~mL}$, then $5 \mathrm{~mL}$ of the $100 \mathrm{~mL}$ of liquid was used to determine the P concentration. The $P$ concentrations in different organs were determined by the molybdenum-stibium antispectrophotometry method (UV-1800 Spectrophotometer, Shanghai Meipuda Instrument Co. Ltd., Shanghai, China) [26].

\subsection{Statistical Analysis}

$\mathrm{P}$ accumulations in leaves, stems, roots, and seeds were obtained by multiplying the respective $\mathrm{P}$ concentrations by the corresponding DWs. The whole plant $\mathrm{P}$ accumulations were obtained by adding the $\mathrm{P}$ accumulations in all organs; and $\mathrm{P}$ partitioning to leaves, stems, roots, or seeds $(\%)=(\mathrm{P}$ accumulations in leaves, stems, roots, or seeds $) \times$ $100 /$ whole plant $\mathrm{P}$ accumulation. The $\mathrm{P}$ acquisition efficiency $\left(\mathrm{mg} \mathrm{g}^{-1}\right)=$ whole plant $\mathrm{P}$ accumulation/root dry weight. The $\mathrm{P}$ harvest index $(\mathrm{PHI}, \%)=(\mathrm{P}$ accumulation in seeds $\times$ 100)/whole plant $P$ accumulation.

Linear models were used to fit the relationships between the dry matter partitioning and the $\mathrm{P}$ partitioning, seed yield and $\mathrm{P}$ accumulation in different organs, seed yield, and $\mathrm{P}$ acquisition efficiency. A three-way analysis of variance (ANOVA) was conducted using the GenStat 19.0 statistical package (VSN International Ltd., Rothamsted, England) to show the effects of water treatments, P levels, cultivars, and their interactions on the determined traits. The least significant difference (LSD) values at $p=0.05$ are shown in parentheses and the LSD values in Table 1 were used to test whether the traits determined in this study significantly differed between the two genotypes. 
Table 1. Significance of sources of variability for genotypes $(\mathrm{G})$, phosphorus levels $(\mathrm{P})$, water treatments $(\mathrm{W})$, and their interactions in Huangsedadou (HD) and Zhonghuang $30(\mathrm{ZH})$ under two water regimes (well-watered (WW) and cyclic water stress (WS)) and three P rates (0 (P0), 60 (P60), and 120 (P120) $\mathrm{mg} \mathrm{P} \mathrm{kg}^{-1}$ dry soil).

\begin{tabular}{|c|c|c|c|c|c|c|c|}
\hline Source of Variability & G & W & $\mathbf{P}$ & $\mathbf{G} \times \mathbf{W}$ & $\mathbf{G} \times \mathbf{P}$ & $\mathbf{W} \times \mathbf{P}$ & $\mathbf{G} \times \mathbf{W} \times \mathbf{P}$ \\
\hline Seed yield (g plant ${ }^{-1}$ ) & $* * *(1.4)$ & $* * *(1.4)$ & $* * *(1.7)$ & $* * *(2.0)$ & $* *(2.4)$ & $* * *(2.4)$ & $* * *(3.4)$ \\
\hline Root dry weight (g plant ${ }^{-1}$ ) & $* * *(2.7)$ & $* * *(2.7)$ & $* * *(3.3)$ & $* * *(3.8)$ & n.s. & $*(4.7)$ & n.s. \\
\hline Shoot dry weight (g plant ${ }^{-1}$ ) & $* * *(5.1)$ & $* * *(5.1)$ & $* * *(6.3)$ & $* * *(7.8)$ & $* *(8.8)$ & $* * *(8.8)$ & *(12.5) \\
\hline Leaf $\mathrm{P}$ concentration $\left(\mathrm{mg} \mathrm{g}^{-1}\right)$ & $* * *(0.2)$ & $* * *(0.2)$ & $* * *(0.2)$ & $* *(0.2)$ & $* * *(0.3)$ & $*(0.3)$ & n.s. \\
\hline Stem $\mathrm{P}$ concentration $\left(\mathrm{mg} \mathrm{g}^{-1}\right)$ & n.s. & n.s. & $* * *(0.5)$ & n.s. & $* * *(0.7)$ & $* *(0.7)$ & n.s. \\
\hline Root $\mathrm{P}$ concentration $\left(\mathrm{mg} \mathrm{g}^{-1}\right)$ & $* * *(0.7)$ & $*(0.7)$ & $* *(0.8)$ & n.s. & n.s. & n.s. & n.s. \\
\hline Seed $\mathrm{P}$ concentration $\left(\mathrm{mg} \mathrm{g}^{-1}\right)$ & $* * *(0.4)$ & $* *(0.4)$ & $* * *(0.5)$ & $* * *(0.6)$ & n.s. & n.s. & $* * *(1.1)$ \\
\hline Leaf $\mathrm{P}$ accumulation (mg) & $* * *(3.6)$ & n.s. & $* * *(4.4)$ & $*(5.1)$ & n.s. & n.s. & n.s. \\
\hline Stem $\mathrm{P}$ accumulation (mg) & $* * *(14)$ & $* * *(14)$ & $* * *(18)$ & $* *(20)$ & * $(25)$ & $* * *(25)$ & n.s. \\
\hline Root $\mathrm{P}$ accumulation (mg) & n.s. & $* *(9)$ & $* * *(11)$ & n.s. & n.s. & n.s. & n.s. \\
\hline Seed $\mathrm{P}$ accumulation (mg) & n.s. & $* * *(17)$ & $* * *(21)$ & n.s. & n.s. & $* * *(30)$ & n.s. \\
\hline Whole plant $\mathrm{P}$ accumulation (mg) & $* * *(28.5)$ & $* * *(23.2)$ & $* * *(28.4)$ & $* * *(40.2)$ & n.s. & $* * *(40.2)$ & $* *(69.7)$ \\
\hline $\mathrm{P}$ acquisition efficiency $\left(\mathrm{mg} \mathrm{g}^{-1}\right)$ & $* * *(1.8)$ & $* * *(1.8)$ & $* * *(2.2)$ & $* * *(2.5)$ & $* * *(3.1)$ & $*(3.1)$ & $* *(4.4)$ \\
\hline Leaf P partitioning (\%) & $* * *(1.7)$ & $* * *(1.7)$ & $* *(2.1)$ & n.s. & n.s. & $* *(2.8)$ & n.s. \\
\hline Stem $\mathrm{P}$ partitioning $(\%)$ & $* * *(4.9)$ & $*(4.9)$ & n.s. & n.s. & $* *(8.4)$ & $*(8.4)$ & n.s. \\
\hline Root P partitioning (\%) & n.s. & n.s. & n.s. & n.s. & n.s. & n.s. & n.s. \\
\hline Seed P partitioning (\%) & $* * *(5.4)$ & n.s. & $*(6.6)$ & n.s. & $* *(9.4)$ & n.s. & n.s. \\
\hline P harvest index (\%) & $* * *(5.3)$ & n.s. & $*(6.5)$ & n.s. & $* *(9.1)$ & n.s. & n.s. \\
\hline
\end{tabular}

n.s., not significant; ${ }^{*} p<0.05,{ }^{* *} p<0.01,{ }^{* * *} p<0.001$. Least significant difference (LSD) values at $p=0.05$ are in parentheses.

\section{Results}

\subsection{The Yield Performance of Soybean Cultivars under Different Water and P Levels}

The seed yield was significantly decreased under cyclic water stress, P deficit, and combined water and P deficit conditions (Table 1; Figure 1). The seed yield of cultivar Zhonghuang 30 was significantly higher than that of Huangsedadou at P60 and P120 under cyclic water stress conditions and P0 under well-watered conditions, but Zhonghuang 30 had a significantly lower seed yield than Huangsedadou at P60 and P120 under wellwatered conditions (Figure 1). Moreover, P application significantly increased the seed yield under both well-watered and cyclic water stress conditions (Table 1; Figure 1A). Cultivar Zhonghuang 30 had a significantly higher PHI than Huangsedadou under all treatment combinations (Figure 1B). 

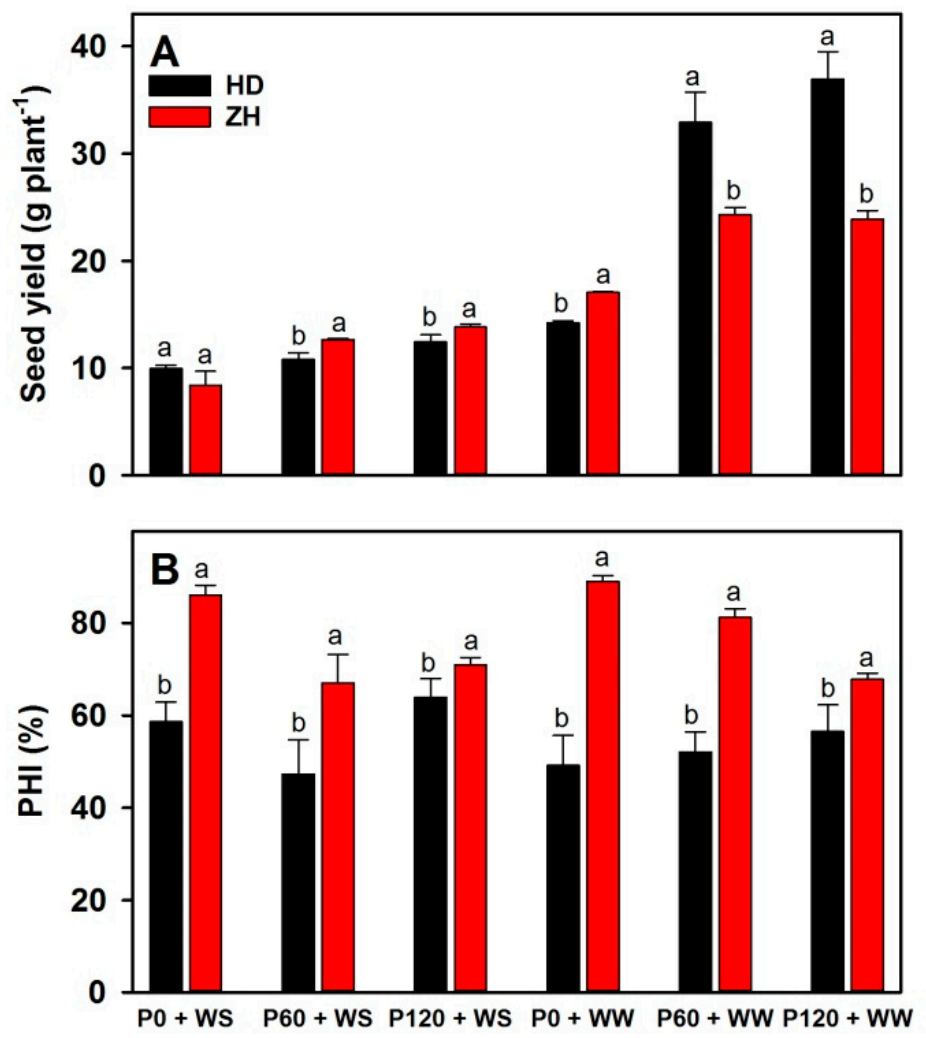

Figure 1. The (A) grain yield and (B) phosphorus harvest index (PHI) of two cultivars (Huangsedadou (HD) and Zhonghuang $30(\mathrm{ZH})$ ) under two water regimes (well-watered (WW) and cyclic water stress (WS)) and three P rates (0 (P0), 60 (P60), and 120 (P120) $\mathrm{mg} \mathrm{P} \mathrm{kg}^{-1}$ dry soil). Means ( \pm SE) with different letters in the same panel are significantly different at $p=0.05$.

\subsection{P Concentrations and Accumulations in Different Organs under Different Water and P Levels}

The $\mathrm{P}$ application significantly increased the concentrations and accumulations of $\mathrm{P}$ in different organs at maturity (Table 1; Figure 2). Cultivar Zhonghuang 30 had a significantly lower stem $\mathrm{P}$ concentration at $\mathrm{P} 0$ and $\mathrm{P} 60$ but was higher at P120 under both cyclic water stress and well-watered conditions (Figure $2 \mathrm{C}$ ). The root $\mathrm{P}$ concentration was significantly higher in Zhonghuang 30 than in Huangsedadou at maturity (Figure 2E). Zhonghuang 30 had a significantly higher seed P concentration than Huangsedadou at P0 under cyclic water stress conditions and for the three P levels under well-watered conditions (Figure 2G). The leaf and stem $\mathrm{P}$ concentrations under cyclic water stress were lower than the leaf and stem $\mathrm{P}$ concentrations when well-watered (Table 1; Figure 2A,C), while the interaction between water treatment and $\mathrm{P}$ levels only had a significant effect on leaf and stem $\mathrm{P}$ concentrations at maturity (Table 1). The leaf $\mathrm{P}$ accumulation in Zhonghuang 30 was lower than $\mathrm{HD}$ at (Figure 2B,D), the two soybean cultivars had the same root and seed $\mathrm{P}$ accumulation under cyclic water stress (Figure 2F,G). 

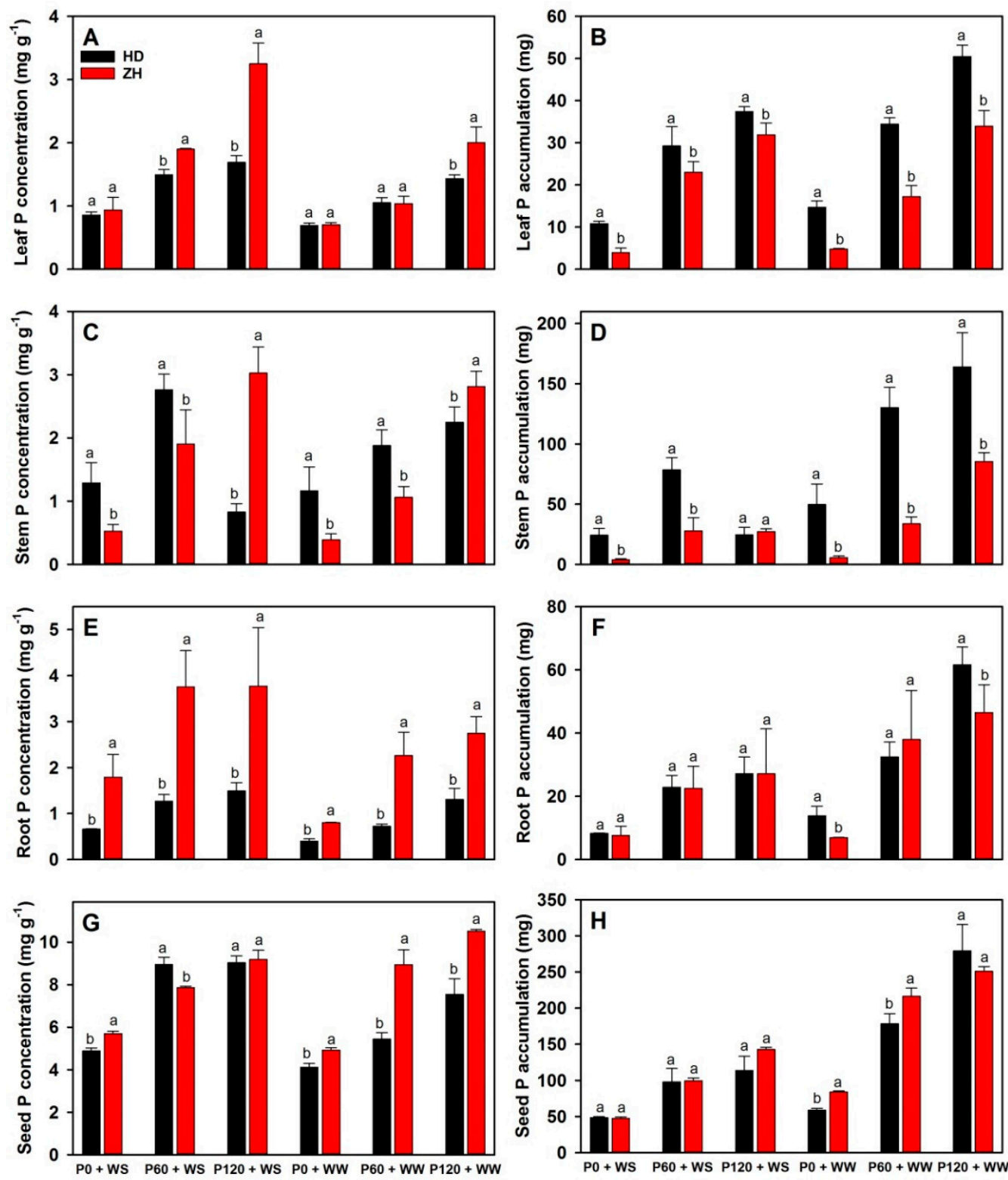

Figure 2. The $P$ concentration and accumulation in $(\mathbf{A}, \mathbf{B})$ leaf, $(\mathbf{C}, \mathbf{D})$ stem, $(\mathbf{E}, \mathbf{F})$ root, and $(\mathbf{G}, \mathbf{H})$ seed of two cultivars (Huangsedadou (H+-+-D) and Zhonghuang $30(\mathrm{ZH})$ ) under two water regimes (well-watered (WW) and cyclic water stress (WS)) and three P rates (0 (P0), 60 (P60), and 120 (P120) $\mathrm{mg} \mathrm{P} \mathrm{kg}^{-1}$ dry soil) at maturity. Means ( \pm SE) with different letters in the same panel are significantly different at $p=0.05$.

\subsection{Dry Matter Accumulation and P Acquisition Efficiency under Different Water and P Levels}

The $P$ application significantly increased the shoot and root dry weight, whole plant $\mathrm{P}$ accumulation, and $\mathrm{P}$ acquisition efficiency, and $\mathrm{ZH}$ had a significantly lower shoot and root dry weight in all treatment combinations (Table 1; Figure 3A,B). Application of $\mathrm{P}$ increased the whole plant $\mathrm{P}$ accumulation under the two water regimes; the whole plant $\mathrm{P}$ accumulations were significantly higher for well-watered conditions than for cyclic water stress in all treatment combinations (Table 1; Figure 3C). Cultivar Zhonghuang 30 had significantly lower $\mathrm{P}$ accumulation but a significantly higher $\mathrm{P}$ acquisition efficiency than Huangsedadou in all treatment combinations (Figure 3C,D). 

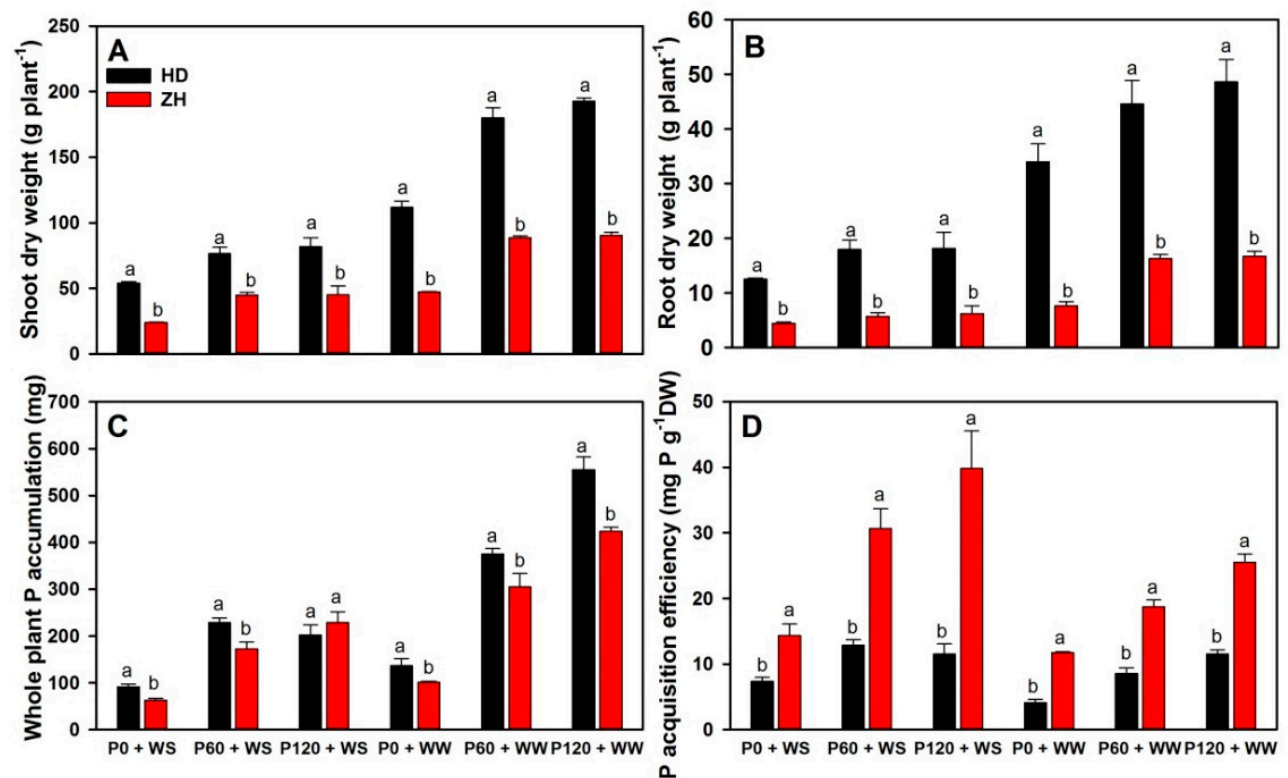

Figure 3. The (A) shoot dry weight, (B) root dry weight, (C) whole plant $\mathrm{P}$ accumulation, and (D) $\mathrm{P}$ acquisition efficiency at maturity in two cultivars (Huangsedadou (HD) and Zhonghuang $30(\mathrm{ZH})$ under two water regimes (well-watered (WW) and cyclic water stress (WS)) and three P rates (0 (P0), 60 (P60), and 120 (P120) mg P kg ${ }^{-1}$ dry soil). Means ( \pm SE) with different letters in the same panel are significantly different at $p=0.05$.

\subsection{The Response of P Partitioning to Different Water and P Levels}

The $P$ application significantly increased the $P$ partition to leaf and seed but had no effect on the P partition to stem and root (Table 1; Figure 4A). Across all treatments, the $\mathrm{P}$ partitioning to leaves and stem in Zhonghuang 30 was significantly lower than in Huangsedadou (Table 1; Figure 4A,C). There was no difference in the P partitioning to roots between Zhonghuang 30 and Huangsedadou (Figure 4B). Cultivar Zhonghuang 30 had significantly higher $\mathrm{P}$ in seeds than Huangsedadou for all treatment combinations (Figure 4D).
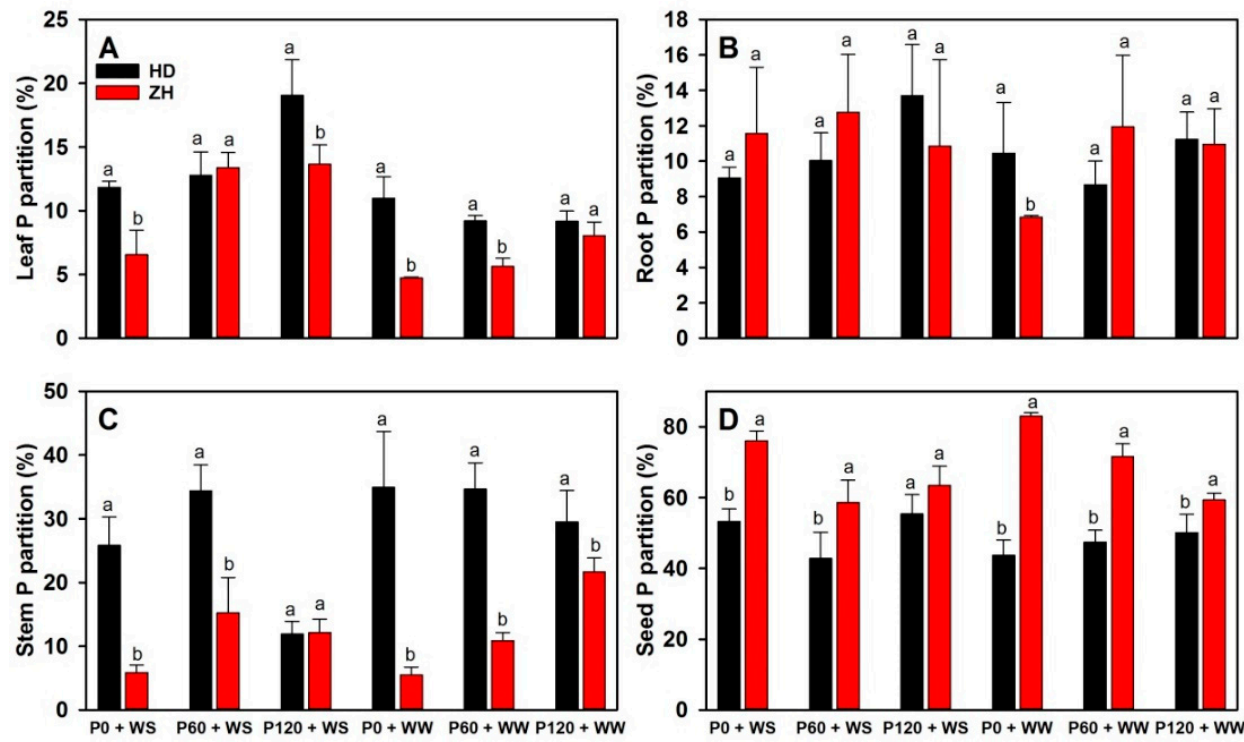

Figure 4. The P partitioning to (A) leaf, (B) stem, (C) root, and (D) seed in two cultivars (Huangsedadou (HD) and Zhonghuang $30(\mathrm{ZH})$ ) under two water regimes (well-watered (WW) and cyclic water stress (WS)) and three $\mathrm{P}$ rates $(0$ (P0), 60 (P60), and 120 (P120) $\mathrm{mg} \mathrm{P} \mathrm{kg}^{-1}$ dry soil) at maturity. Means ( \pm SE) with different letters in the same panel are significantly different at $p=0.05$. 


\subsection{Correlation Analysis}

P partitioning was correlated with dry matter partition (Figure 5A, 5B, 5D), except in root (Figure 5C). Seed yield was positively correlated with $P$ acquisition efficiency at maturity for cyclic water stress (Figure 6A). Seed yield was positively correlated to $\mathrm{P}$ accumulation in seed (Figure 6B), leaf (Figure 6D), stem (Figure 6E) and root (Figure 6F) under well-watered conditions, and in seed (Figure 6B) and leaf P (Figure 6D) under cyclic water stress (Figure 6D-F). The seed yield was not correlation with the $\mathrm{P}$ partition in seed (Figure 6C), leaf (Figure 6G), stem (Figure 6H) and root (Figure 6I).
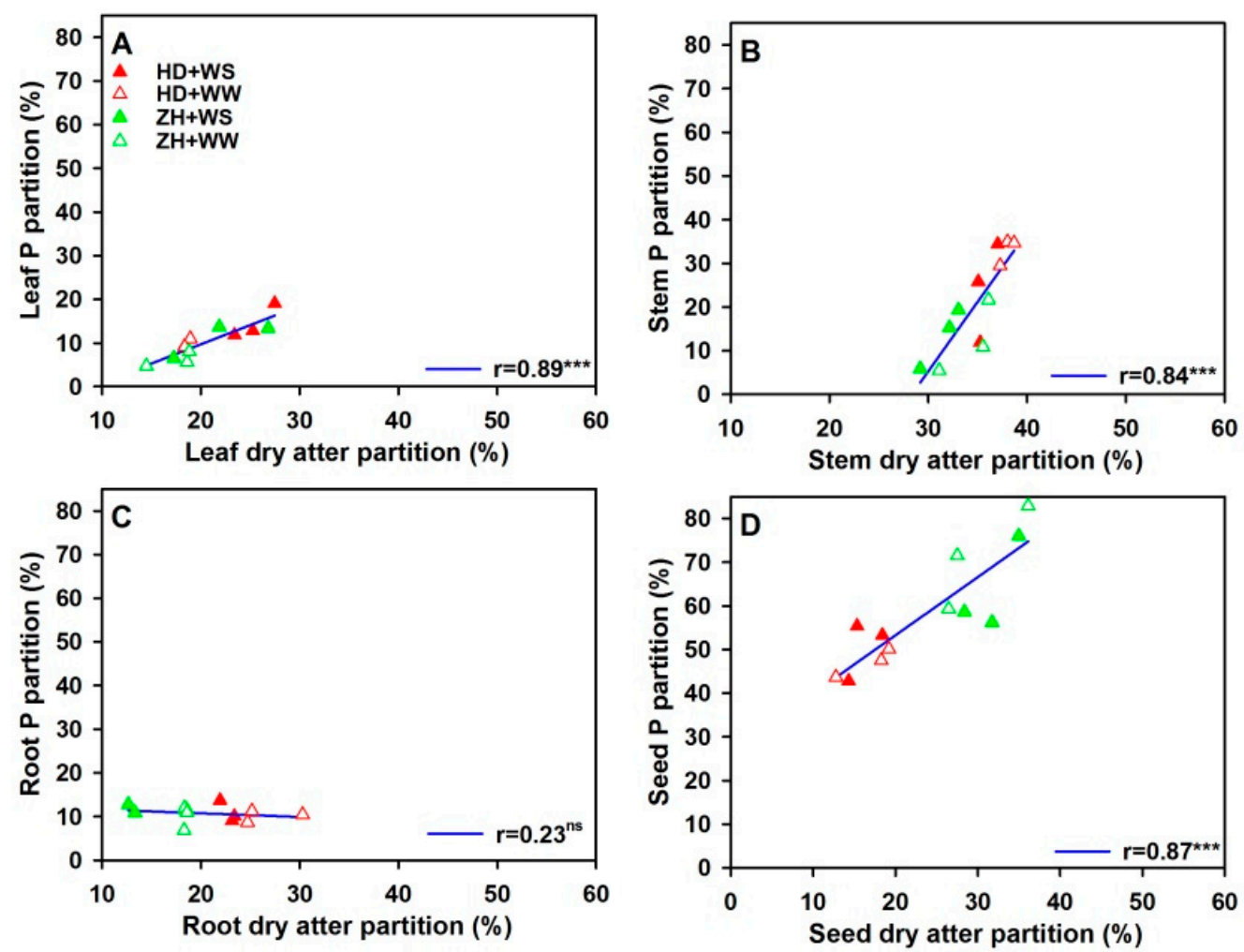

Figure 5. The relationship between (A) leaf dry matter partition and leaf P partitioning, (B) stem dry matter partition and root $\mathrm{P}$ partitioning, $(\mathbf{C})$ root dry matter partition and stem $\mathrm{P}$ partitioning, and (D) seed dry matter partition and seed $\mathrm{P}$ partitioning at maturity under two water regimes (well-watered (WW) and cyclic water stress (WS)) and three P rates (0 (P0), 60 (P60), and 120 (P120) $\mathrm{mg} \mathrm{P} \mathrm{kg}^{-1}$ dry soil). n.s., not significant, ${ }^{* * *} p<0.001$. 

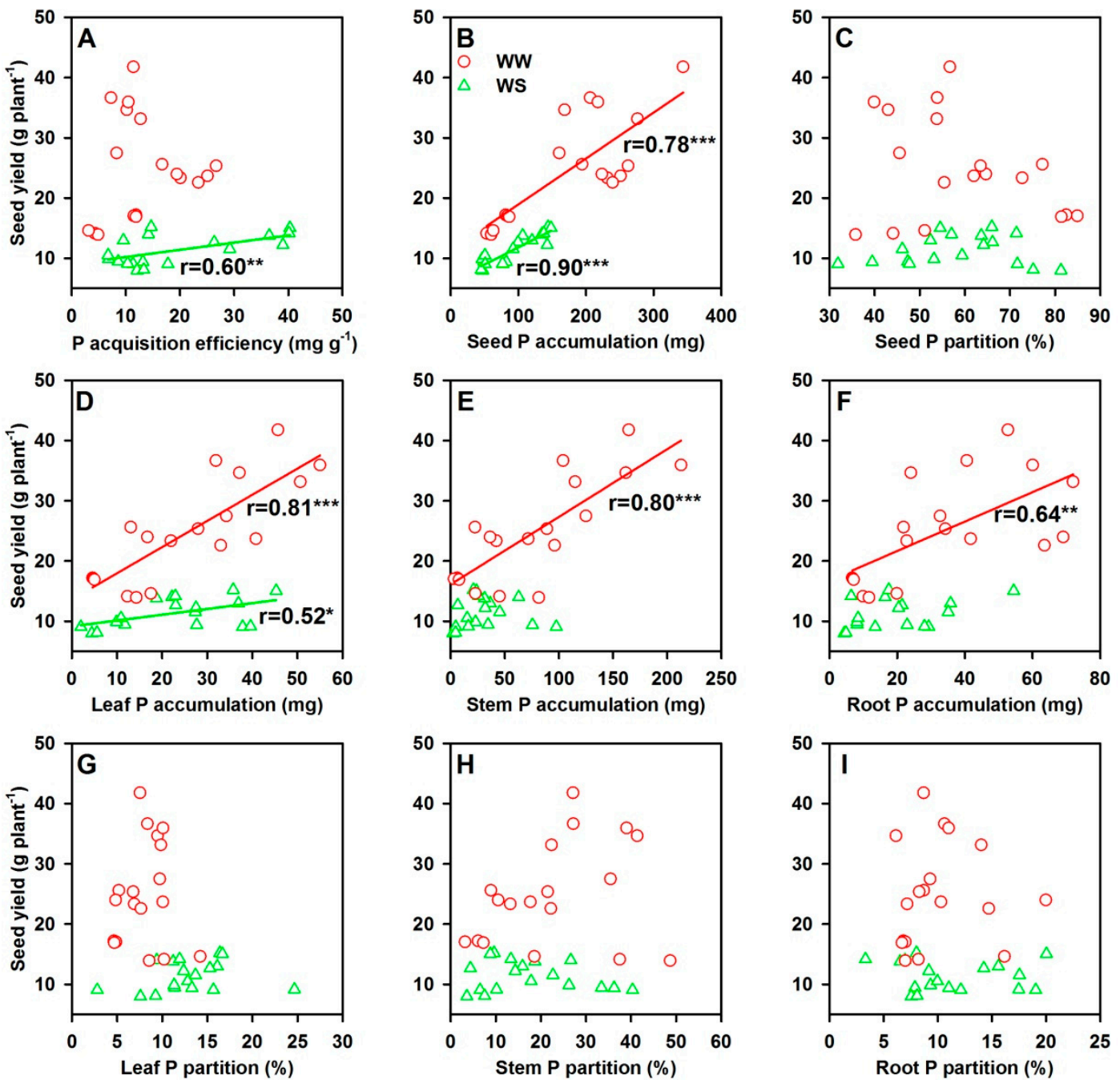

Figure 6. The relationship between the seed yield and $\mathrm{P}$ acquisition efficiency (A), seed $\mathrm{P}$ accumulation (B) and partition $(\mathbf{C})$, leaf $\mathrm{P}$ accumulation $(\mathbf{D})$ and partition $(\mathbf{G})$, stem $\mathrm{P}$ accumulation $(\mathbf{E})$ and partition $(\mathbf{H})$, root $\mathrm{P}$ accumulation $(\mathbf{F})$ and partition (I) under two water regimes (well-watered (WW) and cyclic water stress (WS)) and three P rates (0 (P0), 60 (P60), and 120 (P120) $\mathrm{mg} \mathrm{P} \mathrm{kg}^{-1}$ dry soil). ${ }^{*} p<0.05,{ }^{* *} p<0.01,{ }^{* * *} p<0.001$.

\section{Discussion}

\subsection{Response of P Uptake and Partition to Water and P Deficits}

In this study, $\mathrm{P}$ application significantly increased the $\mathrm{P}$ concentration in different organs, as observed in other studies [31,32]. The root P concentration was significantly higher for Zhonghuang 30 than for Huangsedadou under all treatment combinations, suggesting that a high $\mathrm{P}$ concentration was required to maintain the high $\mathrm{P}$ acquisition efficiency. The P concentration in the leaves and stems was significantly lower under well-watered conditions than cyclic water stress (leaves, 1.69 vs. 1.15; stems, 2.12 vs. 1.37), and the effect of the interaction between water treatment and $P$ rates on leaf and stem $P$ concentrations was significant. These results indicate that an adequate water supply could improve the P mobilization from the leaves and stems, and so improve P use efficiency and contribute to yield improvement.

Application of P significantly increases soybean shoot and root growth [10,26,31,33,34], but the effects of P supply on P partitioning are not well-known. Across all genotypes and treatments, the $\mathrm{P}$ application significantly increased the $\mathrm{P}$ partitioning to leaves at maturity (from $8.5 \%$ at $\mathrm{P} 0$ to $10.3 \%$ at $\mathrm{P} 60$ to 12.5 at $\mathrm{P} 120$ ), because increasing the leaf $\mathrm{P}$ plays an important role in leaf photosynthesis [35], which is associated with dry matter 
accumulation [36]. Additionally, we found that the interaction between water treatment and $P$ rates significantly influenced the $P$ partitioning to leaves and seeds, while cyclic water stress significantly increased the P partitioning to leaves $(12.9 \%$ vs. $8.0 \%)$ but reduced P partitioning to stems (22.6\% vs. $17.6 \%)$. These results support the following assumptions: (1) water supply increased P mobilization in the leaves and more P partitioning to stems may increase resistance to lodging, which causes yield loss under well-watered conditions [37]; (2) more P was needed to maintain the leaf function under cyclic water stress; and (3) a tradeoff between $P$ partitioning to leaves and stems may cause an acclimating strategy under cyclic water stress.

\subsection{P Acquisition and Partitioning Strategy and Yield Performance}

In this study, we found that dry matter partitioning was linked to $\mathrm{P}$ partitioning in leaves, stems, and seeds but not roots. Thus, the aboveground dry matter partitioning was the driver for aboveground $\mathrm{P}$ partitioning. The $\mathrm{P}$ partitioning significantly differed between Zhonghuang 30 and Huangsedadou at maturity. Cultivar Zhonghuang 30 had significantly higher seed $\mathrm{P}$ partitioning than Huangsedadou, which was associated with lower $\mathrm{P}$ retention in leaves and roots. High seed $\mathrm{P}$ partitioning was associated with high seed yield for P60 and P120 under cyclic water stress and P0 under well-watered conditions in Zhonghuang 30; however, high seed P partitioning was not related to high seed yield at P60 and P120 in well-watered conditions because the average shoot dry weight across P60 and P120 for well-watered Zhonghuang 30 was only 48\% of the shoot dry weight in Huangsedadou, which limited the yield potential of Zhonghuang 30. Moreover, the $\mathrm{P}$ harvest index was not correlated with seed yield in this study (data not shown), which is not consistent with the results of Araújo et al. [16] who found that $P$ harvest index was positively correlated with seed yield in the common bean. One explanation is that only two soybean genotypes were used in this study, and more genotypes are needed to verify the relationship between $\mathrm{P}$ harvest index and seed yield in the future. Thus, the high seed $P$ partitioning may have facilitated yield formation when water and $\mathrm{P}$ were limited but played a minor role in yield formation when they were not limited.

In this study, the $\mathrm{P}$ acquisition efficiency improved the yield performance under cyclic water stress at maturity as observed in our previous study [10], and the high P-uptake efficiency is associated with high adventitious and lateral root density [22,26]. Correlative analysis showed that the seed yield was related to the P accumulation in leaves, stems, and roots under well-watered conditions, whereas under cyclic water stress, seed yield was associated with P accumulation in leaves and seeds but not stems and roots. Additionally, seed yield was not correlated with $\mathrm{P}$ partitioning to different organs, indicating that $\mathrm{P}$ accumulation was more important than $\mathrm{P}$ partitioning in determining yield performance.

\section{Conclusions}

In this study, two soybean genotypes with contrasting root dry weight were used to compare the $\mathrm{P}$ status, acquisition, and partitioning, and identify their roles in yield formation, under two water regimes and three $P$ rates. We found that (1) adequate water supply improved the $\mathrm{P}$ mobilization in leaves and stems, which improved the $\mathrm{P}$ use efficiency; and (2) high $\mathrm{P}$ acquisition efficiency and high seed $\mathrm{P}$ partitioning may have facilitated yield formation when water and $\mathrm{P}$ were limited but played a minor role in yield formation when they were not limited.

Author Contributions: The listed authors contributed to this work as described in the following: J.H. and Y.J., conceptualization, gave the concepts of this work; J.H. designed all experiments and provided financial support; Y.-Y.F., investigation and writing-original draft; J.H., Y.J. and F.-M.L., reviewing and editing the manuscript, methodology, and formal analysis. All authors have read and agreed to the published version of the manuscript.

Funding: This research was funded by the National Natural Science Foundation of China (32060427, 31860115), the Guizhou Science and Technology Support Program Project (Qiankehezhichen (2019) 
2399), the Guizhou Provincial Biology First-Class Subject Construction Project (GNYL (2017) 009), and the Provincial Nation-class Discipline of Biology Foundation.

Institutional Review Board Statement: Not applicable.

Informed Consent Statement: Not applicable.

Data Availability Statement: Not applicable.

Conflicts of Interest: The authors declare no conflict of interest.

\section{References}

1. Ososki, A.L.; Kennelly, E.J. Phytoestrogens: A review of the present state of research. Phytother. Res. 2003, 17, 84-869. [CrossRef]

2. Sakai, T.; Kogiso, M. Soyisofl avones and immunity. J. Med. Investig. 2008, 55, 167-173. [CrossRef]

3. Friedman, M.; Brandon, D.L. Nutritional and health benefits of soy proteins. J. Agric. Food Chem. 2001, 49, 1069-1086. [CrossRef]

4. Abbas, M.; Monib, M.; Rammah, A.; Fayez, M.; Hegazi, N. Intercropping of sesbania (Sesbania sesban) and leucaena (Leucaena leucocephala) with five annual grasses under semi-arid conditions as affected by inoculation with specific rhizobia and associative diazotrophs. Agronomy 2001, 21, 517-525. [CrossRef]

5. Sample, E.C.; Soper, R.J.; Racz, G.J. Reaction of phosphate fertilizers in soils. In The Role of Phosphorus in Agriculture; Khasawneh, F.E., Sample, E.C., Kamprath, E.J., Eds.; American Society of Agronomy: Madison, WI, USA, 1980; pp. $263-310$.

6. Stevenson, F.J. Cycles of Soil: Carbon, Nitrogen, Phosphorus, Sulfur, Micronutrients; John Wiley \& Sons Inc.: New York, NY, USA, 1986.

7. Cordell, D.; Drangert, J.O.; White, S. The story of phosphorus: Global food security and food for thought. Glob. Environ. Chang. 2009, 19, 292-305. [CrossRef]

8. Yan, X.L.; Wu, P.; Ling, H.Q.; Xu, G.H.; Xu, F.S.; Zhang, Q.F. Plant nutriomics in China: An overview. Ann Bot. 2006, $98,473-482$. [CrossRef]

9. Lynch, J.P. Root phenes for enhanced soil exploration and phosphorus acquisition: Tools for future crops. Plant Physiol. 2011, 156, 1041-1049. [CrossRef]

10. He, J.; Du, Y.L.; Wang, T.; Turner, N.C.; Yang, R.P.; Siddique, K.H.M.; Li, F.M. Genotypic variation in yield, yield components, root morphology and architecture, in soybean in relation to water and phosphorus supply. Front. Plant Sci. 2017, 8, 1499. [CrossRef]

11. Jia, X.; Liu, P.; Lynch, J.P. Greater lateral root branching density in maize (Zea mays L.) improves phosphorus acquisition from low phosphorus soil. J. Exp. Bot. 2018, 69, 4961-4970. [CrossRef]

12. Miller, C.R.; Ochoa, I.; Nielsen, K.L.; Beck, D.; Lynch, J.P. Genetic variation for adventitious rooting in response to low phosphorus availability: Potential utility for phosphorus acquisition from stratified soils. Funct. Plant Biol. 2003, 30, 973-985. [CrossRef]

13. Walk, T.C.; Jaramillo, R.; Lynch, J.P. Architectural tradeoffs between adventitious and basal roots for phosphorus acquisition. Plant Soil. 2006, 279, 347-366. [CrossRef]

14. Rangarajan, H.; Postma, J.; Lynch, J.P. Co-optimization of axial root phenotypes for nitrogen and phosphorus acquisition in common bean. Ann. Bot. 2018, 122, 485-499. [CrossRef]

15. Mori, A.; Fukuda, T.; Vejchasarn, P.; Nestler, J.; Pariasca-Tanaka, J.; Wissuwa, M. The role of root size versus root efficiency in phosphorus acquisition in rice. J. Exp. Bot. 2016, 67, 1179-1189. [CrossRef]

16. Araújo, A.P.; Teixeira, M.G. Nitrogen and phosphorus harvest indices of common bean cultivars: Implications for yield quantity and quality. Plant Soil 2003, 257, 425-433. [CrossRef]

17. Wang, S.L.; Tian, Q.Z.; Li, N.N.; Xie, L.J.; Pei, T.T.; Li, H. Differences of phosphorus utilization among different wheat varieties. J. Triticeae Crop. 2008, 28, 476-483.

18. Lu, Y.L.; Lu, W.P.; Lu, D.L.; Wang, J.F.; Liu, X.B. The genetic differences in phosphorus distribution and translocation in waxy corn. Sci. Agric. Sin. 2009, 42, 1559-1567. [CrossRef]

19. Wang, J.Y.; Hu, D.Y.; Sun, J.; Tang, X.Y.; Chen, G.D. Phosphorus use efficiency in barley near-isogenic lines of plant height. J. Triticeae Crop. 2019, 39, 364-371.

20. Manavalan, L.P.; Guttikonda, S.K.; Tran, L.S.P.; Nguyen, H.T. Physiological and molecular approaches to improve drought resistance in soybean. Plant Cell Physiol. 2009, 50, 1260-1276. [CrossRef]

21. Frederick, J.R.; Camp, C.R.; Bauer, P.J. Drought-stress effects on branch and mainstem seed yield and yield components of determinate soybean. Crop Sci. 2001, 41, 759-763. [CrossRef]

22. He, J.; Du, Y.L.; Wang, T.; Turner, N.C.; Yang, R.P.; Jin, Y.; Xi, Y.; Zhang, C.; Cui, T.; Fang, X.W.; et al. Conserved water use improves the yield performance of soybean (Glycine max (L. Merr.)) under drought. Agri. Water Manag. 2017, 179, 236-245. [CrossRef]

23. He, J.; Jin, Y.; Turner, N.C.; Li, F.M. Irrigation during flowering improves subsoil water uptake and grain yield in rainfed soybean. Agronomy 2020, 10, 120. [CrossRef]

24. Suriyagoda, L.D.; Ryan, M.H.; Renton, M.; Lambers, H. Plant responses to limited moisture and phosphorus availability. Adv Agron. 2014, 124, 143-200.

25. Jin, J.; Wang, G.; Liu, X.; Pan, X.; Herbert, S.J.; Tang, C. Interaction between phosphorus nutrition and drought on grain yield, and assimilation of phosphorus and nitrogen in two soybean cultivars differing in protein concentration in grains. J. Plant Nutr. 2006, 29, 1433-1449. [CrossRef] 
26. He, J.; Jin, Y.; Turner, N.C.; Chen, Z.; Liu, H.Y.; Wang, X.L.; Siddique, K.H.M.; Li, F.M. Phosphorus application increases root growth, improves daily water use during the reproductive stage, and increases grain yield in soybean subjected to water shortage. Environ. Exp. Bot. 2019, 166, 103816. [CrossRef]

27. Turner, N.C.; Molyneux, N.; Yang, S.; Xiong, Y.C.; Siddique, K.H.M. Climate change in south-west Australia and north-west China: Challenges and opportunities for crop production. Crop Pasture Sci. 2011, 62, 445-456. [CrossRef]

28. He, J.; Du, Y.L.; Wang, T.; Turner, N.C.; Xi, Y.; Li, F.M. Old and new cultivars of soya bean (Glycine max L.) subjected to soil drying differ in abscisic acid accumulation, water relations characteristics and yield. J. Agron. Crop Sci. 2016, 202, 372-383. [CrossRef]

29. Turner, N.C. Imposing and maintaining soil water deficits in drought studies in pots. Plant Soil 2019, 439, 45-55. [CrossRef]

30. Fehr, W.; Caviness, C.; Burmood, D.; Pennington, J. Stage of development descriptions for soybeans, Glycine max (L.) Merrill. Crop Sci. 1971, 11, 929-931. [CrossRef]

31. Hammond, J.P.; Broadley, M.R.; White, P.J.; King, G.J.; Bowen, H.C.; Hayden, R.; Meacham, M.C.; Mead, A.; Overs, T.; Spracklen, W.P.; et al. Shoot yield drives phosphorus use efficiency in Brassica oleracea and correlates with root architecture traits. J. Exp. Bot. 2009, 60, 1953-1968. [CrossRef]

32. Rose, T.J.; Mori, A.; Julia, C.; Wissuwa, M. Screening for internal phosphorus utilisation efficiency: Comparison of genotypes at equal shoot content is critical. Plant Soil 2015, 401, 79-91. [CrossRef]

33. Sandana, P. Phosphorus uptake and utilization efficiency in response to potato genotype and phosphorus availability. Eur. J. Agron. 2016, 76, 95-106. [CrossRef]

34. Sandral, G.A.; Haling, R.E.; Ryan, M.H.; Price, A.; Pitt, W.M.; Hildebrand, S.M.; Fuller, C.G.; Kidd, D.R.; Stefanksi, A.; Lambers, H.; et al. Intrinsic capacity for nutrient foraging predicts critical external phosphorus requirement of 12 pasture legumes. Crop Pasture Sci. 2018, 69, 174-182. [CrossRef]

35. Reich, P.B.; Oleksyn, J.; Wright, I.J. Leaf phosphorus influences the photosynthesis-nitrogen relation: A Cross-Biome Analysis of 314 Specie. Oecologia 2009, 160, 207-212. [CrossRef]

36. Roucou, A.; Violle, C.; Fort, F.; Roumet, P.; Ecarnot, M.; Vile, D. Shifts in plant functional strategies over the course of wheat domestication. J. Appl. Ecol. 2018, 55, 25-37. [CrossRef]

37. Xiang, D.B.; Guo, K.; Lei, T.; Yu, X.B.; Luo, Q.M.; Yang, W.Y. Effects of phosphorus and potassium on stem characteristics and lodging resistance of relay cropping soybean. Chin. J. Oil Crop Sci. 2010, 32, 395-402. 